\title{
Academic Psychiatry versus Patient Care-A Personal View
}

\author{
Victor S. Nehama, Consultant Psychiatrist, Prestwich Hospital, Manchester
}

Teaching and research and Membership Examination orientation, this is the new religion and the major preoccupation now of every 'good' psychiatrist. There is a growing attitude that day-to-day patient care, unless there is a new experiment or innovation, is too familiar and therefore contemptible, and consultants have better things to do. Is it not time to reserve some credit to old-fashioned good patient care, to which all medical people, even the most academic, pay lip service. After all, to win resources doctors have usually to prove to the public the bencfits to patient care and not to teaching and research.

Within an NHS with limited resources excessive academic preoccupation does compete with and impair patient care, e.g. the psychiatric teaching unit in the general hospital dependent on and depleting the resources of the local psychiatric hospital.' Many people who have reservations about being treated under the NHS in a teaching unit, where 'they have no time for you'. opt for private care.

To quote the late Sir Denis Hill: 'I would be the last person to defend my academic brethren on the grounds that they are good psychotherapists... The two ways of thinking do not appear to be compatible."

Research workers have been aptly described as 'hens laying golden eggs", with the implication they are mainly expert at research being otherwise somewhat vulnerable and should receive care and protection.

It may be argued that teaching units attract extensive resources and in fact give better patient care- but at what price? The experiment is uncontrolled: give similar chances and resources to a well motivated non-teaching unit and compare the results. ${ }^{3}$

I am not a dissident: I would be quitc alarmed if psychiatrists opted for a consumer and administratively orientated service under the slogan 'Patient Care'; but I believe those who are neither inefficient nor complacent should be allowed to continue to worship, so to speak, their old god. They could still teach their juniors something. Admittedly industrial and professional relationships have changed so much that the pride of patient care and the implied sense of paternal devotion, which were the hallmark of the psychiatrist's status have become questionable and devalued. Nowadays we even talk about laissez-faire and abdicationism. ${ }^{\text {.t. }}$

In some regions the preoccupation with teaching and research is such that two tiers of psychiatrists are being created, the approved and applauded academic elite and the vast poor nation of 'others'. We are told this is unavoidable because of the dwindling number of approved trainees. To remedy the situation a sterile 'consultants only' service has been suggested. It is not clear whether University Departments of Psychiatry will specially produce 'drones' for 'consultants only' services or, intentionally or unintentionally, create a vast majority of 'vital misfits', i.c. vital for the Health Service.

Teaching and research are absolutely vital for the survival and growth of the psychiatric profession, but there is more to psychi. atry than teaching and research and these are not identical with patient care. Many academic psychiatrists are preoccupied with bridging the elusive gap between medicine and psychiatry, a gap which has always appeared deceptively narrow, e.g. the organic basis of psychiatry. There is an urgent need for more research directly into the most basic aspects of patient care. Intervicw techniques, the corner-stone of communication and psychotherapy, have only recently attracted interest: 'There is so much more for psychiatrists to learn about this very influential phenomenon which takes place between the patient (the one who suffers) and the physician (the one who wishes to help)."

Within the College, and within the Membership Examination, should not there be an emphasis on the art and therapy of patient care, as distinct from psychiatric science? Psychiatric units visited by the Approval Team which are clearly seen to give an example of good patient care, down to earth practical psychotherapy including communication with patients and staff, sensitivity to ward milieu, and communication in multidisciplinary groups within the hospital and in the community, should be approved in general psychiatric training without 100 much demanded in terms of academic achievements.

There is a recent awareness among psychiatrists of the gulf between academic psychiatry and patient management and the need to fill it by extensive exposure of trainees at an early stage to basic psychotherapy at ward level. ${ }^{7}$ May I suggest it should also be at out-patient, multidisciplinary and community levels?

'No-one except you and the patient really knows what happens when you take him for interview ... Scientific medical training is not geared to the ... demands of psychiatry ... The position of a psychiatrist is fairly awesome but is attained through the ability to pass factual exams, not through personal qualities. "In the Membership Examination, 'seeing the candidate "communicate" with the patient" is one way of testing the validity of this concept. However, such essential skills can only be acquired through adequate apprenticeship."

General psychiatry is becoming a Cinderella with no place among the 'prestigious' sections of the College. It is being regarded as the 'rest of psychiatry', and is not readily amenable to organization. But general psychiatry remains the heart of patient care. At a recent Divisional Meeting members were at a loss to coin a name for it as a specialty, when 'Adult Psychiatry' was suggested psychogeriatricians protested that they too deal with adult psychiatry! May I suggest 'Section of the Psychiatry of Patient Care' implying direct and exclusive patient care. This would certainly boost the morale of a large number of psychiatrists who feel somewhat that they no longer belong. 
REFERENCES

'Russell. G.. Granvill.e-Grossman, K. L. \& Brandon, S. (1978) Report to the Working Party: Medical manpower requirements of teaching hospitals (adult psychiatry). Bulletin of the Royal College of Psychiarrists. Decemher. p.2.

:HiL. D. (1982) In conversation with Sir Denis Hill: Parts I and II Bulletin of the Royal College of Psychiatrists. 6, 74-77: 94-97.

'Brown. J. C. (1976) The place of the teaching hospital in psychiatry News and Notes (Supplement to the British Journal of Psychiatry), March. pp. 6-7.

+WALK. A. (1982) Is medical abdicationism widespread? (Correspondence) Bulletin of the Royal College of Psychiatrists, 6, 34

'Nehama, V. S. (1982) Medical abdicationism. (Correspondence)
Bulletin of the Royal College of Psychiatrists, 6, 65

'Romano. J. (1982) Chapter in Psychiatrists on Psychiatry (ed. M. Shepherd). Cambridge University Press.

'Lifberman. S. \& Cobr. J. (1983) Psychotherapy supervision: The atti. tudes of general psychiatrists. Bulletin of the Royal College of Psychiatrists. 7. 102-103.

xAdams. G. P. \& Cook. M. A. (1984) Beginning psychiatry. Bulletin of the Royal College of Psychiatrists. 8, 53-54.

'Berrios, G. E. (1982) The MRCPsych examination. Bulletin of the Royal College of Psychiatrists, 6, 221-22.

"COOPER. S. G. (1983) Reassessing the MRCPsych. (Correspondence) Bulletin of the Royal College of Psychiatrists. 7, 30.

\section{Forthcoming Events}

Cruse and the Inotitute of Family Therapy announce a course of ten seminars and discussion groups on 'A Family Approach to Dying and Bereavement' beginning on 15 January 1985 and to be held at the Institute of Family Therapy, 43 Cavendish Street, London W1. The course is open to all those in the caring professions who work with the dying and the bereaved. Information: Jane Reardon, Course Chairman, Cruse House, 126 Sheen Road, Richmond, Surrey TW9 IUR.

The 21 st Annual Congress of the Royal Australian and New Zealind College of Poychintriats will be held in Hobart, Tasmania, from 5 to 10 May 1985. The theme will be 'Intimacy and Isolation: The Young Adulthood of Psychiatry'. Topics receiving special attention include: issues relevant to women; schizophrenia; and post-traumatic stress disorder. Information: The Tour Company, 335 Moray Street, South Melbourne, Victoria 3205, Australia.

The Institute of Group Analysis is offering a workshop on 'Group Analysis Applied: Activating Other Networks' from 2 to 6 January 1985 at the Institute. The workshop aims to explore some of the wider areas of applying group-analytic principles, particularly in education, in the caring proressions and in looking at transcultural problems. Informa- tion (enclosing an s.a.e.): Institute of Group Analysis, 1 Daleham Gardens, London NW3 5BY.

A two-day course in Family Psychintry for Trainee Psychiatrists will be held on 13 and 14 June 1985 at the Insitute of Family Psychiatry, Ipswich Hospital. Programmes and application forms are available from the Secretary. The Institute of Family Psychiatry, Ipswich Hospital, 23 Henley Road, Ipswich IP1 3TF.

The Forenaic Paychiatry Specialist Section will hold its annual conference at Stratford-on-Avon on 1 and 2 February 1985. The subject is the Homicide Act, 1957, with emphasis on Section 2. Only a limited number of places are available. Applications should be sent to: Dr Paul Bowden, Maudsley Hospital, Denmark Hill, London SE5 8AZ.

A Hospice Psychiatriats Conference will be held in Leeds on 24 and 25 April 1985, organized jointly by St Christopher's Hospice and the Department of Psychiatry, the University of Leeds. Information: Mrs Wendy Brown, Conference Secretary, Department of Psychiatry, 15 Hyde Terrace, Leeds LS2 9LT.

\section{Gifts and Christmas Cards from the College}

College Ties: Single crested in gold, black and silver on backgrounds of either dark blue, green or maroon in polyester ( $f 4.00$ each plus 25 p post and packing) or $100 \%$ silk ( $£ 7.00$ each, postage as above); multi-crested on dark blue background in crimplene ( $\$ 4.00$ each, postage as above). Postage and packing for overseas air mail: $£ 1.00$.

Plaques: Wood shields in light oak with hand painted crest raised in colours (approximately $\left.7^{\prime \prime} \times 6^{\prime \prime}\right)-£ 7.00$ each plus $£ 1.00$ post and packing (overseas surface mail: $£ 1.50$ ).

Ladies Silk Scarves: Cream background with narrow black, red and gold border and College crest in each corner in black, red and gold- $\$ 20.00$ each plus $35 p$ post and packing (air mail postage: $\mathbf{f 1 . 7 5}$ ).

Prints: $18^{\prime \prime} \times 23^{\prime \prime}$ limited edition print of the College from an original watercolour by Dr John Horder, numbered and signed by the artist- $\$ 20.00$ inclusive of post and packing; $10 \frac{1}{3} \times 14 \frac{1}{2}^{\prime \prime}$ print- $\$ 5.00$ inclusive of post and packing.

Christmas Cards: Pictorial card of the print-25p each including post and packing. 